Ilmu Pertanian (Agricultural Science)

Vol. 4 No. 3 December, 2019: 140-145

Available online at http://journal.ugm.ac.id/jip

DOI: doi.org/10.22146/ipas.26029

\title{
Root Morphology and Growth Response of Oil Palm (Elaeis guineensis Jacq) Hybrid to Al Toxicity at Nursery
}

\author{
Tri Utami ${ }^{1}$, Eka Tarwaca Susila Putra ${ }^{2 *}$, Tohari ${ }^{2}$ \\ ${ }^{1}$ Alumnus of Faculty of Agriculture, Gadjah Mada, University, Yogyakarta, Indonesia \\ ${ }^{2}$ Department of Agronomy, Faculty of Agriculture, Universitas Gadjah Mada \\ Jln. Flora no. 1, Bulaksumur, Sleman, Yogyakarta 55281, Indonesia \\ *Corresponding author: eka.tarwaca.s@ugm.ac.id
}

Received: 16 ${ }^{\text {th }}$ June 2017; Revised: 30 ${ }^{\text {th }}$ October 2019; Accepted: 08 ${ }^{\text {th }}$ November 2019

\begin{abstract}
The aim of this study was to determine the response of eight oil palm hybrids to aluminum (Al) toxicity through their growth and root morphological changes. The research was conducted in Sleman, Yogyakarta in June 2014-June 2015. The study was prepared in a Factorial Randomized Block Design, consisting of three blocks as replications. The first factor was the addition of aluminum in two rates $(0 \mathrm{ppm}$ and $300 \mathrm{ppm})$. The second factor was the use of eight oil palm hybrids (Yangambi, Avros, Langkat, PPKS 239, Simalungun, PPKS 718, PPKS 540 and Dumpy). The research was conducted at nursery stage. Observed variables include total root length, total root area, root volume, root diameter, aluminum uptake in root, fractal dimension, and fresh and dry root and shoot weight. The data obtained were analyzed by analysis of variance (ANOVA) at $\alpha=5 \%$ level, followed by Duncan Multiple Range Test (DMRT) to determine the significant difference between the treatments. Aluminum at $300 \mathrm{ppm}$ significantly changed the morphological characteristic of root, thereby inhibiting root growth and biomass. All the hybrids performed the same root morphological and growth variables responses.
\end{abstract}

Keywords: aluminum, hybrids, root, seedling

\section{INTRODUCTION}

Oil palm (Elaeis guineensis Jacq) is an important crop as a world oil producer widely cultivated in Malaysia, Indonesia, and Thailand (Wilcove and Koh, 2010). The soil in wet tropical environment is generally acid and typical of most land area across Indonesia. There are $67 \%$ of the total land area in Indonesia that reacts acids spread out in oil palm development areas. In acidic soils, which account for about $40 \%$ of the earth's land, aluminum $\left(\mathrm{Al}^{3+}\right)$ toxicity has been identified as a major limiting factor in crop productivity (Taylor, 1991).

Under acidic conditions, Al mineral solubilizes into trivalent $\mathrm{Al}^{3+}$, which is highly toxic to animals, plants and microbes (Zioła-Frankowska and Frankowski, 2018). Acidic soil has various syndromes including nutrient deficiency and mineral toxicity. In some cases, Al plays the role in maintaining the nutrient balance in plants through inhibitory effects on toxic minerals and stimulatory effect on deficient nutrients (Muhammad et al., 2018). The toxicity of aluminum is associated with root growth inhibition (Taylor, 1988). Rooting system becomes short and stubby as a result of inhibition of primary and lateral root (Foy, 1974). Al tolerance in plants has therefore been associated with increased accumulation of $\mathrm{Al}^{3+}$ in the rhizosphere and roots but reduced concentration in photosynthetic shoots (Sanjay et al., 2018).

The case of Aluminum toxicity has become an alarming problem, and the incidence continues to increase over time (Shafaqat et al., 2011). Some approaches can be taken to overcome the problem of Aluminum toxicity, such as the use of aluminum resistant hybrids and agronomic manipulations. However, information related to oil palm hybrids resistant to Aluminum toxicity is still limited, yet not existed.

The resistance of an oil palm hybrid against $\mathrm{Al}$ toxicity is thought to be expressed in shoot or root. The expression on rooting system due to Aluminum toxicity allegedly arises earlier, therefore the studies 
to recognize oil palm hybrids resistant to Aluminum toxicity based on rooting character are important to be conducted.

\section{MATERIALS AND METHODS}

The research was conducted in Bendosari, Madurejo, Prambanan, Sleman, Yogyakarta and Laboratory of Crop Science and Production, Faculty of Agriculture, Universitas Gadjah Mada in June 2014-July 2015. The research was arranged in Randomized Complete Block Design (RCBD) with two factors of treatment. The first factor was the addition of aluminum in two rates ( $0 \mathrm{ppm}$ and $300 \mathrm{ppm})$. The second factor was eight oil palm hybrids (Yangambi, Avros, Langkat, PPKS 239, Simalungun, PPKS 718, PPKS 540 and Dumpy) produced by the Indonesian Oil Palm Research Institute (IOPRI).

This research used double stage nursery system, in which the germinated seeds of oil palm were grown in pre-nursery for three months then continued with main nursery for 9 months. Aluminum was applied in the eight week after transplanting from pre-nursery to the main nursery. Aluminum application was carried out using Aluminum sulfate compound with $17 \% \mathrm{Al}_{2} \mathrm{O}_{3}$ at a concentration of $300 \mathrm{ppm}$ which is the critical threshold of Al toxicity on oil palm seedlings (Sutarta and Winarna, 2009). Aluminum was dissolved first in water and then applied along with watering. Aluminum application was given to the plant through watering to the media as solution at a volume of 0.5 liters per plant per day.

Plant height was measured from the base of the stem (above soil surface) to the longest leaf tip. The number of leaves was observed by counting the number of leaves that exist on each plant, starting on the youngest leaves that have been opened perfectly. The measurement of stem diameter was performed using a digital vernier calipers at $1 \mathrm{~cm}$ above soil surface.

Root and shoot biomass were observed at 48 weeks after transplanting at the main nursery. The root and shoot fresh weight were observed right away after the oil palm seedlings were harvested. Root and shoot dry biomass were calculated based on oven dry weight at temperature of $60-80^{\circ} \mathrm{C}$ for at least 48 hours until a constant weight. Total root length and area were measured at 48 weeks after transplanting at the main nursery. Total root length was measured with line intersection read by video camera area meter (Indradewa, 2002). The length of root then was converted to the root standard. Copper wire with a range of diameter as root standard was used (Indradewa, 2002).
The root projection on area meter was measured to get the root surface area with assumption that the root has cylindrical shape so that the root area projection is $=2 r p$, in which $\mathrm{r}$ is the radius, and $\mathrm{p}$ is the root length, thus $r$ value can be calculated. The root surface area is $=2 \pi r p$ (Indradewa, 2002). Root diameter then was calculated ( $2 r$ of the root surface area). The root volume was observed by using volumetric method.

Fractal dimension was observed with box counting method. The root system was placed on the needle pin-board then cleaned from the soil by watering. After that, the root system was placed under the square frame with some length variation which were (r) $1 ; 2 ; 2,5 ; 4 ; 5 ; 10 ; 12,5 ; 20 ; 25$; and $50 \mathrm{~cm}$ with frame size of $1 \mathrm{~m} \times 1 \mathrm{~m}$. (Tatsumi et al., 1989). The intersection between the boxes and roots was then counted as $N(r)$. After that, $\log r$ in every size of boxes (r) was determined. A regression then was made with $\log N(r)$ as dependent variable $(Y)$ and $\log$ $(r)$ as independent variable $(X)$. The equation is as follow: $\log N(r)=-D \log r+\log K$, where $K$ (intercept) is constant and $\mathrm{N}(r)=-D$ (Eghball, 1993). The Fractal dimension $(D)$ is in a range of $1 \leq D \leq 2$.

Aluminum content in root and shoot was determined after digestion in $\mathrm{HNO}_{3}$ and $\mathrm{HClO}_{4}$ with Atomic Absorption Spectronic (AAS). Aluminum absorbed (Al Abs) in shoot and root was counted with formula by Frageria et al. (1988); Astutiningsih (2005), in which: $\mathrm{Al} \mathrm{Abs}=\mathrm{Al}$ Content $\times \mathrm{Wd}$, where $\mathrm{Wd}$ is dry weight.

The response of root and shoot growth to aluminum toxicity was analyzed by Fischer and Maurer (1978) equation as follow:

$$
\Delta \text { Response }=\frac{Y \text { control }-Y \text { toxicity }}{Y \text { control }} \times 100 \%
$$

Data were analyzed with analysis of variance (ANOVA) and continued with Duncan's Multiple Range Test at $\alpha=5 \%$.

\section{RESULTS AND DISCUSSION}

Root is the most important organ in absorbing nutrient and water because the root lies in the planting medium. If the soil is contaminated, the root will be the first organ affected before other organs such as stem or leaf are affected. Marschner (1986) states that nutrients are absorbed from the smelly complex or from a solution in a planting medium of cation and anion. Proklamasiningsih et al. (2012) state that the form of aluminum compound on various $\mathrm{pH}$ of 
Table 1. Al Content and absorption in root tissue of oil palm hybrids at 48 weeks after transplanting

\begin{tabular}{lcc}
\hline Treatment & $\begin{array}{c}\text { Al content in root } \\
\text { tissue }(\mathrm{ppm})\end{array}$ & $\begin{array}{c}\text { Al absorption } \\
\text { in Root }(\mathrm{mg})\end{array}$ \\
\hline Al Treatment & & \\
\hline 0 ppm & $7106.05 \mathrm{~b}$ & $207.42 \mathrm{a}$ \\
$300 \mathrm{ppm}$ & $12494.07 \mathrm{a}$ & $159.01 \mathrm{~b}$ \\
\hline Oil palm hybrids & & \\
\hline Yangambi & $10968.57 \mathrm{p}$ & $183.00 \mathrm{p}$ \\
Avros & $10840.48 \mathrm{p}$ & $219.63 \mathrm{p}$ \\
Langkat & $11130.84 \mathrm{p}$ & $225.73 \mathrm{p}$ \\
PPKS 239 & $8767.56 \mathrm{p}$ & $170.45 \mathrm{p}$ \\
Simalungun & $9025.28 \mathrm{p}$ & $192.57 \mathrm{p}$ \\
PPKS 718 & $9294.40 \mathrm{p}$ & $163.85 \mathrm{p}$ \\
PPKS 540 & $9264.03 \mathrm{p}$ & $145.63 \mathrm{p}$ \\
Dumpy & $9109.32 \mathrm{p}$ & $164.85 \mathrm{p}$ \\
\hline Interaction & $(-)$ & $(-)$ \\
\hline CV & 18.16 & 29.82 \\
\hline
\end{tabular}

Remark: Means followed by the same letters in the same column are not significantly different based on Duncan's multiple range test at $\alpha=5 \%$; (-) indicates there is no interaction between the factors.

Table 2. Al content in leaf tissues of oil palm hybrids at 48 weeks after transplanting

\begin{tabular}{lcccccccccc}
\hline Al & \multicolumn{7}{c}{ Al Content in leaf Tissue } & Mean \\
\cline { 2 - 9 } Treatment & Yangambi & Avros & Langkat & PPKS 239 Simalungun PPKS 718 & PPKS 540 & Dumpy & \\
\hline $0 \mathrm{ppm}$ & $258.03 \mathrm{k}$ & $534.02 \mathrm{~h}$ & $152.07 \mathrm{n}$ & 215.691 & $160.52 \mathrm{n}$ & $313.85 \mathrm{i}$ & $195.15 \mathrm{~m}$ & $270.63 \mathrm{j}$ & 262.49 \\
$300 \mathrm{ppm}$ & $2327.46 \mathrm{a}$ & $1115.77 \mathrm{e}$ & $1320.90 \mathrm{~d}$ & $924.92 \mathrm{f}$ & $705.50 \mathrm{~g}$ & $1497.66 \mathrm{c}$ & $1910.59 \mathrm{~b}$ & $1307.95 \mathrm{~d}$ & 1381.34 \\
\hline Mean & 1292.74 & 824.89 & 736.48 & 570.30 & 433.01 & 875.75 & 1052.87 & 789.29 & $(+)$ \\
\hline CV & $0.74 \%$ & & & & & & & & \\
\hline
\end{tabular}

Remark: Means followed by the same letters in the same column are not significantly different based on Duncan's multiple range test at $\alpha=5 \%$; (-) indicates there is interaction between the factors.

Table 3. Responses of oil palm hybrids root growth to Al-toxicity at 48 weeks after transplanting

\begin{tabular}{lccccc}
\hline \multirow{2}{*}{ Oil Palm Hybrids } & \multicolumn{5}{c}{$\Delta$ Responses on Root Growth (\%) } \\
\cline { 2 - 6 } Yangambi & Root length & Root area & Root diameter & Root volume & Fractal dimension \\
Avros & $66.06 \mathrm{a}$ & $-1585.49 \mathrm{a}$ & $-5378.19 \mathrm{a}$ & $60.94 \mathrm{a}$ & $4.02 \mathrm{a}$ \\
Langkat & $-1841.57 \mathrm{a}$ & $-3371.23 \mathrm{a}$ & $-26.34 \mathrm{a}$ & $56.32 \mathrm{a}$ & $4.16 \mathrm{a}$ \\
PPKS 239 & $45.72 \mathrm{a}$ & $-1345.96 \mathrm{a}$ & $-3799.99 \mathrm{a}$ & $52.65 \mathrm{a}$ & $2.22 \mathrm{a}$ \\
Simalungun & $50.54 \mathrm{a}$ & $-1818.99 \mathrm{a}$ & $-3491.40 \mathrm{a}$ & $58.57 \mathrm{a}$ & $2.46 \mathrm{a}$ \\
PPKS 718 & $28.01 \mathrm{a}$ & $-2508.13 \mathrm{a}$ & $-3971.00 \mathrm{a}$ & $33.90 \mathrm{a}$ & $-0.76 \mathrm{a}$ \\
PPKS 540 & $-15.90 \mathrm{a}$ & $-2074.56 \mathrm{a}$ & $-820.96 \mathrm{a}$ & $53.17 \mathrm{a}$ & $2.02 \mathrm{a}$ \\
Dumpy & $28.41 \mathrm{a}$ & $-2005.93 \mathrm{a}$ & $-4576.05 \mathrm{a}$ & $43.62 \mathrm{a}$ & $2.48 \mathrm{a}$ \\
\hline Mean & $45.30 \mathrm{a}$ & $-1926.02 \mathrm{a}$ & $-3075.14 \mathrm{a}$ & $52.54 \mathrm{a}$ & $2.32 \mathrm{a}$ \\
\hline CV (\%) & -199.18 & -2079.54 & -3142.38 & 51.46 & 2.36 \\
\hline
\end{tabular}

Remark: Means followed by the same letters in the same column are not significantly different based on Duncan's Multiple Range Test at $\alpha=5 \% ;(*)$ Data were transformed using $\sqrt{ }(\mathrm{X}+0.5)$ 
Table 4. Responses of oil palm hybrids fresh and dry biomass to Al-toxicity at 48 weeks after transplanting

\begin{tabular}{lcccccc}
\hline \multirow{2}{*}{ Oil PalmHybrids } & \multicolumn{2}{c}{$\Delta$ Responses on fresh biomass $(\%)$} & \multicolumn{2}{c}{$\Delta$ Responses on dry biomass $(\%)$} \\
\cline { 2 - 7 } & Root & Shoot & Total & Root & Shoot & Total \\
\hline Yangambi & $49.12 \mathrm{a}$ & $65.44 \mathrm{a}$ & $64.15 \mathrm{a}$ & $63.99 \mathrm{a}$ & $49.98 \mathrm{a}$ & $53.03 \mathrm{a}$ \\
Avros & $27.01 \mathrm{ab}$ & $41.86 \mathrm{ab}$ & $44.33 \mathrm{ab}$ & $65.15 \mathrm{a}$ & $28.14 \mathrm{a}$ & $38.31 \mathrm{a}$ \\
Langkat & $5.06 \mathrm{ab}$ & $32.96 \mathrm{ab}$ & $38.15 \mathrm{ab}$ & $55.07 \mathrm{a}$ & $19.82 \mathrm{a}$ & $32.00 \mathrm{a}$ \\
PPKS 239 & $37.49 \mathrm{ab}$ & $26.60 \mathrm{ab}$ & $29.31 \mathrm{ab}$ & $56.93 \mathrm{a}$ & $37.82 \mathrm{a}$ & $42.40 \mathrm{a}$ \\
Simalungun & $13.50 \mathrm{ab}$ & $12.41 \mathrm{~b}$ & $15.32 \mathrm{~b}$ & $44.65 \mathrm{a}$ & $14.28 \mathrm{a}$ & $21.07 \mathrm{a}$ \\
PPKS 718 & $31.08 \mathrm{ab}$ & $41.54 \mathrm{ab}$ & $41.87 \mathrm{ab}$ & $56.56 \mathrm{a}$ & $34.48 \mathrm{a}$ & $39.90 \mathrm{a}$ \\
PPKS 540 & $-11.14 \mathrm{~b}$ & $34.93 \mathrm{ab}$ & $33.46 \mathrm{ab}$ & $41.85 \mathrm{a}$ & $32.01 \mathrm{a}$ & $33.92 \mathrm{a}$ \\
Dumpy & $25.23 \mathrm{ab}$ & $40.06 \mathrm{ab}$ & $39.13 \mathrm{ab}$ & $51.42 \mathrm{a}$ & $39.54 \mathrm{a}$ & $42.85 \mathrm{a}$ \\
\hline Mean & 22.17 & 36.97 & 38.21 & 54.45 & 32.01 & 37.94 \\
\hline CV (\%) & $16.44^{*}$ & $28.15^{*}$ & $28.13^{*}$ & 22.28 & $26.96^{*}$ & $23.38^{*}$ \\
\hline
\end{tabular}

Remark: Means followed by the same letters in the same column are not significantly different based on Duncan's multiple range test at $\alpha=5 \% ;(*)$ Data were transformed using $\sqrt{ }(X+0.5)$

Table 5. Responses of oil palm hybrids root and shoot biomass to Al-toxicity at 48 weeks after transplanting

\begin{tabular}{lccc}
\hline \multirow{2}{*}{ Oil palm hybrids } & \multicolumn{3}{c}{$\Delta$ Responses on shoot growth (\%) } \\
\cline { 2 - 4 } & Plant height & Total leaf & Stem diameter \\
\hline Yangambi & $15.46 \mathrm{a}$ & $15.85 \mathrm{a}$ & $20.17 \mathrm{a}$ \\
Avros & $7.86 \mathrm{a}$ & $18.75 \mathrm{a}$ & $14.59 \mathrm{a}$ \\
Langkat & $13.64 \mathrm{a}$ & $11.30 \mathrm{a}$ & $14.93 \mathrm{a}$ \\
PPKS 239 & $13.27 \mathrm{a}$ & $4.87 \mathrm{a}$ & $15.85 \mathrm{a}$ \\
Simalungun & $24.50 \mathrm{a}$ & $8.47 \mathrm{a}$ & $14.43 \mathrm{a}$ \\
PPKS 718 & $26.32 \mathrm{a}$ & $12.38 \mathrm{a}$ & $19.75 \mathrm{a}$ \\
PPKS 540 & $23.03 \mathrm{a}$ & $3.93 \mathrm{a}$ & $12.33 \mathrm{a}$ \\
Dumpy & $14.73 \mathrm{a}$ & $3.98 \mathrm{a}$ & $8.48 \mathrm{a}$ \\
\hline Mean & 17.35 & 9.94 & 15.07 \\
\hline CV $(\%)$ & $28.20^{*}$ & $14.46^{*}$ & $22.69^{*}$
\end{tabular}

Remark: Means followed by the same letters in the same column are not significantly different based on Duncan's Multiple Range Test at $\alpha=5 \%$; (*) Data were transformed using $\sqrt{ }(X+0.5)$

planting medium is very influential on the concentration of aluminum in root tissue.

Table 1 shows that there is no interaction between treatments given on the $\mathrm{Al}$ content in plant tissues and its uptake. The addition of Al significantly increased $\mathrm{Al}$ content in plant root tissue at 48 weeks after transplanting, but $\mathrm{Al}$ absorption was higher in plants without $\mathrm{Al}$ addition. This is thought to be related to root dry weight in plants without $\mathrm{Al}$ addition which were higher than the root dry weight in those given $\mathrm{Al} 300 \mathrm{ppm}$. Al absorption value was used to calculate the amount of $\mathrm{Al}$ that can be absorbed by plant roots. Different hybrids showed the same response of Al content and its absorption.

According to the comparison of $\mathrm{Al}$ content in leaves and in roots (Table 1 and Table 2), all the hybrids tested have one of the tolerant criteria. According to Kochian (1995), most of Al is retained in the roots and slightly translocated to the top of the plant. All of the oil palm hybrids tested in this study experienced an increase in $\mathrm{Al}$ concentration in leaf tissues when exposed to Al. Yangambi hybrid showed the highest Al content, while the Simalungun hybrid showed the lowest one. The interaction between $\mathrm{Al}$ application and hybrids shows that each hybrid has different capabilities in storing Al metals in leaf tissues.

Aluminum toxicity is associated with stunted root growth (Taylor, 1988). The inhibition of primary and lateral root extension results in short and stubby root systems (Sopandie, 2013). As shown in Table 3, all of the oil palm hybrids tested gave the same responses, showing the inhibition of root extension, except on 
the Avros and PPKS 718 hybrids that were still capable of performing root extension. All hybrids showed increased values of root diameter. The same response was also observed on root surface area, showing that all hybrids tested increased the root surface area, however, only Simalungun hybrids were able to distribute the roots evenly as shown in the fractal dimension value. According to Yang et al. (2013), the fractal dimension value of $\sim 1$ indicates that the growth of the leaves or roots lies in the rim/root region, while the the fractal dimension value of $\sim 2$ indicates that the leaves/roots are evenly distributed throughout its surface. The response of root volume showed that all hybrids experienced the inhibition of root volume growth. According to Polled and Konzak (1990), root damage by Aluminum causes disruption of nutrient uptake and transport, making it sensitive to drought, thus ultimately affecting plant growth and productivity.

Almost all hybrids tested showed a decrease in fresh weight of both root and shoot as affected by the addition of Al. Yangambi hybrid showed the highest decrease in the fresh weight of root, while PPKS 540 hybrid showed an increase in the root fresh weight. Simalungun hybrid showed the lowest decrease in shoot/canopy fresh weight. However, all hybrids showed the same response, which was the decrease in root and shoot/canopy dry weight (Table 4).This is because the accumulation of dry matter was inhibited, thus decreasing the dry weight of the plant.

Al toxicity can inhibit shoot growth by inhibiting the supply of nutrients, water, and cytokines from roots due to poor root penetration to subsoil or low root hydraulic conditions (Marschner, 1995). The morphological response in the form of root tip thickening inhibits the nutrient uptake, which can interfere with the metabolism process of plants, thereby resulting in the inhibition of plant growth as shown in Table 5.

\section{CONCLUSIONS}

The addition of $\mathrm{Al}$ inhibited root growth as observed on several variables such as root length, root volume, and root surface area. The root diameter was enlarged due to the thickening of root cell as a response to aluminum toxicity. Eight oil palm hybrids performed relatively the same morphological and growth responses.

\section{ACKNOWLEDGEMENT}

The authors would like to thank Ministry of Higher Education, Technology, and Research, Republic of Indonesia for funding this research work.

\section{REFERENCES}

Astutiningsih, W. 2005. Kajian fisiologis cekaman Al dan defisiensi P terhadap pertumbuhan bibit padi gogo dengan tingkat ketahanan yang berbeda. Tesis: Universitas Gadjah Mada. Yogyakarta.

Eghball, B., J.R. Settimi, J.W. Maranville and A.M. Parkhurst. 1993. Fractal analysis for morphological description of corn roots under nitrogen stress. Agronomy Journal, 85: 287-289.

Fischer, R.A. and R. Maurer. 1978. Drought resistance in spring wheat cultivar: I. Grain yield response. Aust. J. Agric. Res., 29: 897-912.

Foy, C. D.1974. Effect of aluminum on plant growth, p. 601-642.In Carson EW.(Ed). The Plant Root and Its Environment. Charlottesville: University of Virginia.

Frageria, N.K., A.B. Santos, M.P.B. Filho, C.M. Guimaraes.2008. Iron toxicity in lowland rice. J. Plant Nutr., 31: 1676-1697.

Indradewa D. 2002. Gatra agronomis dan fisiologis pengaruh genangan dalam parit pada tanaman kedelai. Disertasi. Universitas Gadjah Mada Yogyakarta, Indonesia.

Kochian L.V. 1995. Celluler mechanism of aluminum toxicity and resistance in plant. Ann.Rev.Plant Physiol.Mol.Biol., 46 : 237-260.

Marschner, H. 1986. Mineral nutrition in higher plant. $2^{\text {nd }}$ ed., London: Academic Press Inc., London.

Marschner, H. 1995. Mineral nutrition of higher plant. $2^{\text {nd }}$ ed., USA: Academic Press. New York.

Muhammad, N. Gerald, and Z. Zhang. G. 2018. A review: The beneficial effect of aluminum on plant growth in acid soil and the possible mechanisms. Journal of Integrative Agriculture, 17: 60345-7.

Polled EA and C.F. Konzak. 1990. Genetic and breeding of cereals for acid soil and nutrient efficiency, p. 81-131. In: Balligar V.C Duncan RR (ed.). Crops as Enhancers of nutrient use. Academic Press. San Diego.

Proklamasiningsih, E., I.D. Prijambada, D. Rachmawati dan R.P. Sancayaningsih. 2012. Pengaruh 
pemberian garam aluminium (Al) terhadap serapan Al dan pertumbuhan akar kedelai pada media tanam masam. J. Bionatura, 14: 107-114.

Sanjay K. J, J. Naamala and F. D. Dakora. 2018. Nature and mechanisms of aluminium toxicity, tolerance and amelioration in symbiotic legumes and rhizobia. Biology and Fertility of Soils, 54: 309-318

Shafaqat A., F. Z.B. Qiu, S. Cai, L. Qiu, F. Wu and G. Zhang. 2011. Interactive effects of aluminum and chrominum stresses on the uptake of nutrients and the metals in barley. Soil Science and Plant Nutrition, 57: 68-79.

Sopandie, D. 2013. Fisiologi adaptasi tanaman terhadap cekaman abiotik pada agroekosistem tropika. $1^{\text {st }}$. IPB Press. Bogor.

Sutarta, E.S, dan Winarna. 2009. Pengaruh dosis logam berat terhadap pertumbuhan dan serapan hara bibit kelapa sawit. Jurnal Penelitian Kelapa Sawit, 17: 1-9.
Tatsumi, J., A. Yamauchi and Y. Kono.1989. Fractal analysis of plant root systems. Annal of Botany, 64: 499-503.

Taylor G.J. 1988. The physiology of aluminum phytotoxicity, p. 123-163. In: Sigel H and Sigel A (eds). Metal ions in biological systems: Marcel Dekker Inc., New York.

Taylor G.J. 1991. Current views of the aluminum stress response; the physiological basis of tolerance. Curr Topics Plant Biochem Physiol., 10: 57-93.

Wilcove, D.S. and L.P. Koh. 2010. Addressing the threats to biodiversity from oil palm agriculture. Biodiver. Conserv, 19: 999-1000.

Yang, Y., M. Tang, R. Sulpice, H. Chen, S. Tian, dan Y. Ban. 2013. Arbuscular Mycorrhizal fungi alter fractal dimension characteristics of Robinia pseudoacacia L. seedlings trought regulating plant growth, leaf water status, photosynthesis, and nutrient concentration under drought stress. Jurnal Plant Growth Regul., 344 : 1-12. 